\title{
Population Pharmacokinetic Analysis of Dexmedetomidine in Children using Real- World-Data Obtained from Electronic Health Records and Remnant Clinic Samples
}

\author{
Nathan T. James ${ }^{1}$, Sara Van Driest ${ }^{2,3}$, Prince Kannankeril ${ }^{2}$, Leena Choi ${ }^{1}$
}

Departments of ${ }^{1}$ Biostatistics, ${ }^{2}$ Medicine, and ${ }^{3}$ Pediatrics, Vanderbilt University Medical Center, Nashville, TN.

\begin{abstract}
Dexmedetomidine is commonly used as part of intraoperative anesthetic management and for sedation and pain control after surgery in children. Dexmedetomidine infusion dose is typically given on a fixed weight basis with titration to achieve sedation goals while avoiding potential toxicities. Pharmacokinetic (PK) studies are useful for accurate prediction of the individual dose required to achieve sedation and analgesia goals without toxicity, but lack of PK data is a challenge in precision dosing for pediatric populations. In this study, population PK models were developed using a nonlinear mixed-effects modeling approach and used to explore the relationship between PK profile and clinical, demographic, and genotype covariates. A simulation study was used to demonstrate the impact of important covariates on concentration using a fixed weight dosing scheme. Our final study population included data from 354 patients age 0 to 22 years (median age 16 months). In the final two-compartment model with fixed allometric weight scaling we found significant effects of both age and UGT2B10 genotype. The population PK parameter estimates (95\% confidence interval) for a standard $70 \mathrm{~kg}$ weight were clearance $22.3(18.3$ - 27.3) L/hr, central compartment volume of distribution 133 (112 - 157) L, intercompartmental clearance $24.1(19.4-29.9) \mathrm{L} / \mathrm{hr}$, peripheral compartment volume of distribution 5230 (3310 - 8260) L. Our study provides support for the feasibility of using realworld data obtained from EHRs and remnant samples to perform population PK analysis for groups of patients where traditional PK studies are challenging to perform. Inclusion of $U G T 2 B 10$ genotype in the model significantly improved the model fit, but the effects were not large enough to impact clinical dosing.
\end{abstract}

Key Words: Population Pharmacokinetics, Dexmedetomidine, Pragmatic Research, Opportunistic Sampling 
medRxiv preprint doi: https://doi.org/10.1101/2021.05.03.21256553; this version posted May 6, 2021. The copyright holder for this preprint (which was not certified by peer review) is the author/funder, who has granted medRxiv a license to display the preprint in perpetuity.

All rights reserved. No reuse allowed without permission.

\section{Introduction}

Dexmedetomidine is an alpha2-agonist with anxiolytic, sedative and analgesic properties with minimal effects on respiratory depression. ${ }^{1,2}$ The sedative and cardiopulmonary profile of the drug make it an attractive agent for sedation and pain control after surgery in children with congenital heart disease (CHD). Dexmedetomidine is now routinely used as part of the intraoperative anesthetic management during CHD surgical repairs and in the postoperative period in the intensive care unit (ICU). ${ }^{3,4}$ Dexmedetomidine is commonly dosed as a continuous infusion on a fixed weight basis (e.g., starting at $0.3 \mathrm{mcg} / \mathrm{kg} / \mathrm{hr}$ ), with titration of the rate in order to achieve sedation goals while avoiding potential toxicities which include hypotension and bradycardia. Accurate prediction of an individual's dexmedetomidine requirement (precision dosing) could help achieve sedation and analgesia goals without toxicity.

Population pharmacokinetic (PK) models can be useful when drug concentration measurements per subject are limited - as is often the case for pediatric populations - if the number of study subjects is sufficiently large. In addition to allowing estimation of population and individual parameters by "borrowing" information across subjects, these models also quantify variability between subjects. Importantly, population PK models can identify covariates that affect each individual's PK profile, facilitating personalized dosing. Several population PK studies of dexmedetomidine in pediatric populations have been reported, ${ }^{5-17}$ often using a small number of individuals and frequent sample collection [median sample size 29, range 18-199 for pediatric ICU populations]. ${ }^{7,9-12,14,15}$ Strategies to address small sample size include pooled pediatric analyses, ${ }^{17}$ creating "universal" models for both children and adults, ${ }^{6,8}$ and Bayesian analyses with informative priors $;{ }^{16}$ however, even these models only include information from at most around 130 children.

The small sample size limits the ability to identify significant covariates that impact interindividual variability. For example, dexmedetomidine is metabolized into inactive metabolites by 
medRxiv preprint doi: https://doi.org/10.1101/2021.05.03.21256553; this version posted May 6, 2021. The copyright holder for this preprint (which was not certified by peer review) is the author/funder, who has granted medRxiv a license to display the preprint in perpetuity. All rights reserved. No reuse allowed without permission.

glucuronidation (by UGT1A4 and UGT2B10) and hydroxylation (primarily by $C Y P 2 A 6){ }^{2,18}$

Small studies of the impact of genetic variation or expression levels of these enzymes have failed to demonstrate pharmacogenetic associations. ${ }^{19,20}$ A newly developed weighted genetic risk score to predict $C Y P 2 A 6$ activity raises the possibility of better capturing the impact of variants across this gene for pharmacogenetic analysis. ${ }^{21}$ Study of a large cohort may allow the identification of genetic biomarkers affecting dexmedetomidine PK, facilitating precision dosing based on genotype.

Motivated by the challenges of obtaining a larger study population and collecting frequent drug concentration measurements from children, we combined data from electronic health records (EHRs) and remnant samples collected during usual clinical care to perform a population PK analysis. A few previous studies have used similar methodology, including two pediatric fentanyl population PK studies. ${ }^{22,23}$ To our knowledge, ours is the first study to employ this method to perform dexmedetomidine PK analysis for a pediatric population.

While EHR-sourced data provide a great opportunity to perform PK studies with larger sample size, these data require more preprocessing compared to a designed clinical trial and may be subject to additional challenges such as missing or erroneous values and sparse sampling. ${ }^{24}$ To address some of these challenges, we previously developed a system to construct PK analysis datasets using raw data extracted from EHRs. ${ }^{25}$ This is one of the first studies that employed this system using the R package EHR. ${ }^{26}$

The major goals of this study were to develop a dexmedetomidine population PK model for children with data obtained from EHRs and remnant samples and quantify genetic effects that were selected a priori based on previous studies and known metabolic pathways. 
medRxiv preprint doi: https://doi.org/10.1101/2021.05.03.21256553; this version posted May 6, 2021. The copyright holder for this preprint (which was not certified by peer review) is the author/funder, who has granted medRxiv a license to display the preprint in perpetuity. All rights reserved. No reuse allowed without permission.

\section{Methods}

Study Design

This study was approved by the Vanderbilt University Medical Center (VUMC) Institutional Review Board and has been previously described. ${ }^{22}$ In brief, pediatric patients undergoing surgery for CHD are offered enrollment in this observational study. Parents provide written consent for their child's participation, and informed assent is obtained when appropriate. Drug selection and dosing are determined by the primary clinical team. Remnant samples from clinical testing are obtained for drug concentration measurements, which are not disclosed to the clinical teams. Enrollment with remnant specimen collection began in July 2012 and is ongoing. Data analyzed for this study were collected prior to October 2017. All study participants were admitted to the pediatric cardiac ICU after surgery. Enrolled participants were excluded from the analysis if their surgery was cancelled, if there was missing genotype data, if extracorporeal membrane oxygenation (ECMO) treatment was required, or if they did not survive to hospital discharge. For those with multiple surgeries, data from the one procedure with the highest number of measured serum drug concentrations were used, excluding all others. Drug concentrations were excluded if inadequate internal standard concentrations were detected and insufficient volume remained to repeat analysis, or if they were obtained before any documented dexmedetomidine dosing.

\section{Data Collection}

Demographic data (including race, per self-report) and medical history were documented at the time of study enrollment. Surgical and clinical data were extracted from the EHR prospectively by the study team. Dexmedetomidine dosing, including scheduled boluses, as-needed intermittent boluses, and continuous infusions after the postoperative admission to the ICU were 
medRxiv preprint doi: https://doi.org/10.1101/2021.05.03.21256553; this version posted May 6, 2021. The copyright holder for this preprint (which was not certified by peer review) is the author/funder, who has granted medRxiv a license to display the preprint in perpetuity.

All rights reserved. No reuse allowed without permission.

determined from the EHR and the Vanderbilt Enterprise Data Warehouse. The Enterprise Data

Warehouse contains an electronic copy of both nurse administration and pharmacy operational data, enabling the computation of administered drug amounts over specific time periods. Study data were collected and managed using REDCap electronic data capture tools, a secure, webbased application hosted at Vanderbilt University. ${ }^{27}$

\section{Drug Concentration Measurement}

For the purposes of drug concentration analysis, all remnant plasma specimens $\geq 100 \mu \mathrm{L}$ from blood obtained for clinical testing of electrolyte or basic metabolic panels in study subjects were obtained from the Vanderbilt Clinical Chemistry Laboratory. After retrieval, remnant specimens were stored at $-20^{\circ} \mathrm{C}$ until sample processing for drug concentration analysis. Specimen processing and mass spectrometry analysis have been previously described in detail. ${ }^{22}$ Briefly, acetonitrile precipitation was followed by tandem mass spectrometry using a 16-drug assay. Dexmedetomidine assay accuracy is $89-112 \%$, and the lower and upper limits of quantitation are 0.005 and $5 \mathrm{ng} / \mathrm{mL}$, respectively.

\section{Genotyping and CYP2A6 Activity Score Prediction}

All study participants provide a peripheral blood sample for genetic analysis, and study participants have been genotyped using either the Axiom ${ }^{\text {TM }}$ Precision Medicine Research Array or the Precision Medicine Diversity Array. As part of genotype data quality control, variants were removed if genotype call rate was $<98 \%$, and data for individuals were removed if their genotype call rate was $<98 \%$, the genetically estimated sex differed from parental-reported sex, or for relatedness (2nd degree or closer). Genotype data were imputed to the 1000 Genomes 
medRxiv preprint doi: https://doi.org/10.1101/2021.05.03.21256553; this version posted May 6, 2021. The copyright holder for this preprint (which was not certified by peer review) is the author/funder, who has granted medRxiv a license to display the preprint in perpetuity. All rights reserved. No reuse allowed without permission.

phase 3 reference panel. For this study, we extracted data for specific variants in $U G T 2 B 10$ (rs2942857; rs112561475; rs61750900), UGT1A4 (rs2011425; rs3892221; rs6755571) and CYP2A6 (rs56113850; rs2316204; rs113288603; rs28399442; rs1801272; rs28399433) from the study database. For the UGT genes, an additive model counting the number of variant alleles for each individual was calculated. For $C Y P 2 A 6$, enzyme activity was predicted using a polygenic score. $^{21}$

\section{Data Processing}

Data processing was facilitated using a modularized system for postmarketing population PK studies with real-world data from EHRs as described in Choi et al. ${ }^{25}$ This system has been implemented in the $\mathrm{R}$ software ${ }^{28}$ package $\mathrm{EHR}^{26}$ which provides a standardized, scalable pipeline to prepare and integrate demographic data, drug dosing and concentration, and clinical laboratory measurements into a standard data format compatible with most population PK analysis software. Additionally, it incorporates interactive checks for data quality to reconcile missing, duplicate, and other erroneous concentration or dosing information. The data output from the EHR package pipeline was further cleaned by removing: (i) concentration measurements more than 150 hrs (approximately 50 times dexmedetomidine half-life) after the end of the final bolus or infusion dose, (ii) concentration measurements below the lower limit of quantification (LLOQ) of $0.005 \mathrm{ng} / \mathrm{mL}$ if they are after the final bolus or infusion dose, except for the first such measurement, (iii) concentration measurements above the upper limit of quantification (ULOQ) of $5 \mathrm{ng} / \mathrm{mL}$, (iv) subjects whose only concentration measurements are below the LLOQ after applying criteria (i)-(iii), and (v) subjects with missing dose information indicated by increases in concentration without an accompanying dose. 
medRxiv preprint doi: https://doi.org/10.1101/2021.05.03.21256553; this version posted May 6, 2021. The copyright holder for this preprint (which was not certified by peer review) is the author/funder, who has granted medRxiv a license to display the preprint in perpetuity.

All rights reserved. No reuse allowed without permission.

Serum creatinine concentration was a time-varying covariate, which was typically

measured at the same time as dexmedetomidine concentration. If serum creatinine measurement was not available when dexmedetomidine concentration was measured, we selected the serum creatinine concentration measured closest to the dexmedetomidine concentration data within 7 days. For each subject, weight varied little within the timeframe of available concentration data, so most weight data were the same as the baseline demographic measurements. When additional weight measurements were available, typically during infusion, weight measurements obtained at the same time as the concentration data point were used. Measures of albumin concentration were available for only $35 \%$ of subjects and were available within a 7-day window for only 48 subjects, precluding use of albumin concentration as covariate.

\section{Population PK Analysis}

We performed population PK analysis of dexmedetomidine using nonlinear mixedeffects models implemented by Monolix version 2020R $1^{29}$ and estimated the parameters with the stochastic approximation expectation/maximization (SAEM) method. Observed concentrations below the LLOQ were considered to be censored between 0 and $0.005 \mathrm{ng} / \mathrm{mL}$ and were handled in the modeling using the appropriate likelihood for interval censoring. ${ }^{30}$ First, we chose the base model by comparing one- and two-compartment PK models without covariates, assuming a combined additive and proportional residual error model and lognormal distribution for the PK parameter random effects. Then, the combined residual error model was compared to models with only additive or proportional error for the selected compartmental model. Next, weight effects were incorporated as a covariate for all main PK parameters, and the models using fixed versus estimated allometric scaling parameters were compared. 
medRxiv preprint doi: https://doi.org/10.1101/2021.05.03.21256553; this version posted May 6, 2021. The copyright holder for this preprint (which was not certified by peer review) is the author/funder, who has granted medRxiv a license to display the preprint in perpetuity.

All rights reserved. No reuse allowed without permission.

Covariate model building for clearance was performed starting from the weight only model and both graphical and statistical methods were used in model selection. All covariates were chosen a priori based on previous research and biological plausibility, which include three candidate genotype markers (UGT1A4, UGT2B10, and CYP2A6), and the following covariates: age, sex, Society of Thoracic Surgery-European Association for Cardio-Thoracic Surgery (STAT) Congenital Heart Surgery Mortality score, ${ }^{31}$ cardiac bypass time, length of ICU stay, and serum creatinine. For UGT1A4 and UGT2B10, dichotomous models (coding individuals as having a loss-of-function variant or not) and additive models (counting the number of variants) were considered. In addition, based on Badée et al., ${ }^{32}$ we explored the hypothesis that effects of UGT1A4 and UGT2B10 change with age by including an interaction effect between age and genotype. No additional covariates other than weight were considered for modeling other PK parameters.

Statistical model selection was performed using likelihood ratio tests based on the objective function value (OFV). Plots of empirical Bayes estimates (EBEs) versus covariates were examined to detect potential misspecification of the covariate model. Because the SAEM estimation method includes stochastic variability and can sometimes fail to converge in a setting with sparse sampling, ${ }^{33}$ we performed 5 runs with different random seeds for each model and selected the median -2LL for model comparison.

\section{Simulations of Concentration}

To demonstrate the effect of covariates on predicting dexmedetomidine concentration, we estimated predicted concentration-time profiles using PK parameter estimates from the final covariate model. Confidence bounds were produced using quantiles from 200 simulated subjects with residual error (proportional component standard deviation $=0.3 \mathrm{ng} / \mathrm{mL}$, additive component 
medRxiv preprint doi: https://doi.org/10.1101/2021.05.03.21256553; this version posted May 6, 2021. The copyright holder for this preprint (which was not certified by peer review) is the author/funder, who has granted medRxiv a license to display the preprint in perpetuity. All rights reserved. No reuse allowed without permission.

standard deviation $=1.5 \times 10^{-8} \mathrm{ng} / \mathrm{mL}$ ) for the following combination of covariates and dosing groups: (1) the $5^{\text {th }}$, median, or $95^{\text {th }}$ percentile of weight and age; (2) with or without UGT2B10 genotype variants; (3) fixed-weight dose based infusion rates of 0.3 or $0.6 \mathrm{mcg} / \mathrm{kg} / \mathrm{hr}$ for a 12 hour infusion.

In addition, we performed simulations to find the dosing levels that would yield similar concentrations for subjects of the same age and weight with and without variants. First, concentration-time profiles were simulated using identical dosing rate, weight, and age for a subject with and without variants. Then the dosing rate for the subject with variants was adjusted in increments of $0.01 \mathrm{mcg} / \mathrm{kg} / \mathrm{hr}$ until the concentration achieved at the end of the 12hour infusion most closely matched the concentration of the subject without variants. The $\mathrm{R}$ package mrgsolve ${ }^{34}$ was used to perform all simulations.

\section{Results}

Study Population and Specimens

We collected 4,369 residual plasma specimens sent to the clinical core laboratory for providerordered metabolic panel testing from 620 subjects. After removing 165 subjects due to inhospital mortality or ECMO treatment and 44 subjects due to missing dosing or covariate information the output of the EHR package pipeline contained 411 subjects with 2,172 specimens. The further cleaning steps described above removed 11 subjects and 43 more subjects without genotype information were also removed. The final study population $(n=354$, with 1,400 specimens and 2,386 dosing events) is described in Table 1. Around half of the subjects were male $(n=183,52 \%)$ and the median age was 16 months (interquartile range [IQR] $5-62)$. The race of most study subjects was White $(n=293,83 \%)$ or Black $(n=40,11 \%)$ with the remainder in the other or unknown categories. Median weight was $9.4 \mathrm{~kg}$ (IQR $6.0-18.2)$ and median serum 
medRxiv preprint doi: https://doi.org/10.1101/2021.05.03.21256553; this version posted May 6, 2021. The copyright holder for this preprint (which was not certified by peer review) is the author/funder, who has granted medRxiv a license to display the preprint in perpetuity.

All rights reserved. No reuse allowed without permission.

creatinine was $0.49 \mathrm{mg} / \mathrm{dL}$ (IQR $0.44-0.56$ ). Most participants had STAT score 1 or 2 (44\%

and $31 \%$, respectively), denoting low risk for mortality associated with congenital heart surgery

procedures. Median cardiac bypass time was 100 minutes and median length of ICU

hospitalization was 4 days.

There were 262 subjects (74\%) with no variants of $U G T 1 A 4,87(25 \%)$ with 1 variant and $5(1 \%)$ with 2 variants. For $U G T 2 B 10,186$ subjects (53\%) had no variants, $117(33 \%)$ had 1

variant and $51(14 \%)$ had 2 or 3 variants. The $C Y P 2 A 6$ predicted activity score was available for 350 of the 354 subjects in the final study population; for those subjects the median $C Y P 2 A 6$ score was 2.04 (IQR $2.00-2.21$ ). The median number of dosing events per subject was 5 (IQR 3 - 8). The number of sampled specimens per subject varied from a minimum of 1 to a maximum of 18 with a median of 3 specimens (IQR $2-5)$.

\section{Population PK Model}

The results for the base and covariate models are presented in Table 2. A twocompartment model with additive and proportional error was chosen as the base model. From the base model, the parameters as well as their $95 \%$ asymptotic confidence intervals (CIs) were estimated without covariates. The main PK parameters are total clearance (CL, L/hr), volume of distribution for the central compartment $\left(\mathrm{V}_{1}, \mathrm{~L}\right)$, inter-compartmental clearance $(\mathrm{Q}, \mathrm{L} / \mathrm{hr})$ and volume of distribution for the peripheral compartment $\left(\mathrm{V}_{2}, \mathrm{~L}\right)$. The PK parameters varied substantially among individual participants; the coefficients of variation $(\mathrm{CV})$ for $\mathrm{CL}, \mathrm{V}_{1}, \mathrm{Q}$, and $\mathrm{V}_{2}$ were $200 \%, 161 \%, 146 \%$, and $675 \%$, respectively.

Inclusion of weight as covariate for all PK parameters with fixed allometric scaling parameters substantially improved the model fit (OFV decreased by 406 from the base model, Table 2). The model with fixed allometric scaling parameters was selected over the model with 
medRxiv preprint doi: https://doi.org/10.1101/2021.05.03.21256553; this version posted May 6, 2021. The copyright holder for this preprint (which was not certified by peer review) is the author/funder, who has granted medRxiv a license to display the preprint in perpetuity.

All rights reserved. No reuse allowed without permission.

estimated allometric parameters as the latter did not improve the model fit. Additionally, including age improved the model fit from the weight only model (difference in OFV of 9.05,

Table 2). Predicted CL from the age and weight model for seven age groups across a range of plausible weights is shown in Figure 2A (overlap between lines indicates weights that are plausible for multiple ages). No further improvement was seen by adding other covariates to the weight and age model, except for genetic markers.

Models that included weight and either UGT1A4 or UGT2B10 individually were a significant improvement over the weight only model, while including the predicted $C Y P 2 A 6$ activity did not improve the model fit. Inclusion of weight and both genes yielded little improvement over each dominant gene model. Addition of age to the gene models improved model fit compared to the models without age. In contrast, the age by gene interaction model failed to converge for the majority of runs. Thus, the final two covariate models included weight, age, and $U G T 1 A 4$ or $U G T 2 B 10$ with a dichotomous gene model (i.e., any variant vs. no variants). The main part of the model is presented as follows:

$$
\begin{aligned}
& \mathrm{CL}_{\mathrm{i}}=\theta_{1} \times\left(\mathrm{WT}_{\mathrm{i}} / 70\right)^{0.75} \times \exp \left(\theta_{5} \times \mathrm{AGE}_{\mathrm{i}}+\theta_{6} \times \mathrm{I}\left[\mathrm{UGT}_{\mathrm{i}}>0\right]\right) \times \exp \left(\eta_{\mathrm{i}}^{\mathrm{CL}}\right) \\
& \mathrm{V}_{1 \mathrm{i}}=\theta_{2} \times\left(\mathrm{WT}_{\mathrm{i}} / 70\right) \times \exp \left(\eta_{\mathrm{i}}^{\mathrm{V} 1}\right) \\
& \mathrm{Q}_{\mathrm{i}}=\theta_{3} \times\left(\mathrm{WT}_{\mathrm{i}} / 70\right)^{0.75} \times \exp \left(\eta_{\mathrm{i}}^{\mathrm{Q}}\right) \\
& \mathrm{V}_{2 \mathrm{i}}=\theta_{4} \times\left(\mathrm{WT}_{\mathrm{i}} / 70\right) \times \exp \left(\eta_{\mathrm{i}}^{\mathrm{V} 2}\right),
\end{aligned}
$$

where $\mathrm{Cl}_{\mathrm{i}}, \mathrm{V}_{1 \mathrm{i}}, \mathrm{Q}_{\mathrm{i}}$, and $\mathrm{V}_{2 \mathrm{i}}$ are the individual-specific $\mathrm{PK}$ parameters corresponding to $\mathrm{CL}, \mathrm{V}_{1}, \mathrm{Q}$, and $\mathrm{V}_{2}, \mathrm{WT}_{\mathrm{i}}$ is subject weight in kilograms $(\mathrm{kg}), \mathrm{AGE}_{\mathrm{i}}$ is subject age in months, and I[UGT* $*_{\mathrm{i}}>0$ ] is an indicator variable that equals 1 if the subject has any variants and 0 otherwise for UGT1A4 or UGT2B10. The $\eta_{\mathrm{i}}^{\mathrm{CL}}, \eta_{\mathrm{i}} \mathrm{V}_{1}, \eta_{\mathrm{i}}^{\mathrm{Q}}$, and $\eta_{\mathrm{i}} \mathrm{V}^{\mathrm{V}}$ are random effects explaining inter-individual variability for the respective parameters which follow a normal distribution with mean zero and variance of $\omega^{2} \mathrm{CL}, \omega^{2} \mathrm{~V} 1, \omega^{2} \mathrm{Q}$, and $\omega^{2} \mathrm{~V} 2$, respectively. The $\theta \mathrm{s}$ in the equations denote model 
medRxiv preprint doi: https://doi.org/10.1101/2021.05.03.21256553; this version posted May 6, 2021. The copyright holder for this preprint (which was not certified by peer review) is the author/funder, who has granted medRxiv a license to display the preprint in perpetuity.

All rights reserved. No reuse allowed without permission.

parameters as typically used in statistical models. Diagnostic plots for the UGT2B10 model are shown in Figure 1.

The estimates of CL, $\mathrm{V}_{1}, \mathrm{Q}$ and $\mathrm{V}_{2}$ in terms of a standard population with weight of $70 \mathrm{~kg}$ are shown in Table 2: for the UGT1A4 model, CL $\left(\theta_{1}\right)=19.4 \mathrm{~L} / \mathrm{hr}, \mathrm{V}_{1}\left(\theta_{2}\right)=135 \mathrm{~L}, \mathrm{Q}\left(\theta_{3}\right)=$ 28.1 L/hr, and $\mathrm{V}_{2}\left(\theta_{5}\right)=9400 \mathrm{~L}$, and for the $U G T 2 B 10$ model, CL $\left(\theta_{1}\right)=22.3 \mathrm{~L} / \mathrm{hr}, \mathrm{V}_{1}\left(\theta_{2}\right)=133$ $\mathrm{L}, \mathrm{Q}\left(\theta_{3}\right)=24.1 \mathrm{~L} / \mathrm{hr}$, and $\mathrm{V}_{2}\left(\theta_{4}\right)=5230 \mathrm{~L}$. For the final covariate model with UGT1A4, we estimate $\mathrm{CL}, \mathrm{V}_{1}, \mathrm{Q}$ and $\mathrm{V}_{2}$ as $4.4 \mathrm{~L} / \mathrm{hr}, 18.0 \mathrm{~L}, 6.2 \mathrm{~L} / \mathrm{hr}$, and $1262.2 \mathrm{~L}$ for a child with no gene variants, at the median weight of $9.4 \mathrm{~kg}$ and median age of 15.7 months; for the UGT2B10 model, the estimates for a subject with the same covariate values are $\mathrm{CL}=5.1 \mathrm{~L} / \mathrm{hr}, \mathrm{V}_{1}=17.8 \mathrm{~L}$, $\mathrm{Q}=5.3 \mathrm{~L} / \mathrm{hr}$ and $\mathrm{V}_{2}=702.3 \mathrm{~L}$. After inclusion of covariates, the CV for CL was substantially reduced from $200 \%$ estimated in the base model, to $121 \%$ and $124 \%$ in the final models for UGT1A4 and $U G T 2 B 10$, respectively.

\section{Genetic Effects on Clearance and Concentration}

For the UGT2B10 model, the estimated genotype effect was -0.15 (95\% CI: -0.27 to $0.03)$, indicating a $14 \%$ decrease $[\exp (-0.15)=0.86]$ in CL on average for those with any UGT2B10 variants holding age and weight constant. Figure 2B shows predicted CL by genotype for ages $6,12,24,48,72,90$, and 120 months across a range of plausible weights for each age where the overlap between lines indicates weights that could occur for multiple ages. The $14 \%$ decrease in CL associated with $U G T 2 B 10$ variants is the same for all ages, but this proportional decrease translates to larger absolute differences for older subjects. For the UGT1A4 model the estimated genotype effect was -0.076 (95\% CI: -0.26 to 0.11$]$ ), which was not significant at the $\alpha$ $=0.05$ level. Predicted CL by genotype for the UGT1A4 model is included in the Supplemental

\section{Text.}


medRxiv preprint doi: https://doi.org/10.1101/2021.05.03.21256553; this version posted May 6, 2021. The copyright holder for this preprint (which was not certified by peer review) is the author/funder, who has granted medRxiv a license to display the preprint in perpetuity. All rights reserved. No reuse allowed without permission.

Simulation-based comparisons of concentration-time profile for subjects with and without $U G T 2 B 10$ variants are shown in Figure 3. As expected, subjects with $U G T 2 B 10$ variants have higher predicted concentration than those without variants, however the difference between genotypes is much smaller than the residual variability within subjects represented by the colored shaded regions. For a dosing rate of either 0.3 or $0.6 \mathrm{mcg} / \mathrm{kg} / \mathrm{hr}$, steady-state concentration is achieved at around 6 hours and is similar for subjects with $5^{\text {th }}$, median, or $95^{\text {th }}$ percentile of weight and age. For $0.3 \mathrm{mcg} / \mathrm{kg} / \mathrm{hr}$ dosing rate, the predicted concentration steady-state levels are below the target range of 0.4 to $0.8 \mathrm{ng} / \mathrm{mL}$ for subjects with and without variants. In contrast, the $0.6 \mathrm{mcg} / \mathrm{kg} / \mathrm{hr}$ rate yields predicted steady-state concentration levels within the target range for both genotype groups. Figure 4 shows simulated doses needed to achieve same concentration for patients of same age and weight with and without variants.

\section{Discussion}

Using remnant specimen samples along with dosing information, clinical and demographic information sourced from an EHR system we were able to develop a dexmedetomidine population PK model for a large, pediatric cohort of 354 patients and to identify patient characteristics including genetic factors that alter the PK profile. Our study is one of the largest pediatric dexmedetomidine population PK studies reported.

We were able to confirm a structural model and covariate relationships which are in line with those previously reported for dexmedetomidine PK. Specifically, our model confirmed the inclusion of both weight and age effects on CL. We estimated CL of 23.0 L/hr for subjects with a standard weight of $70 \mathrm{~kg}$ and the median age of 15.7 months without variants from the UGT2B10 model. Our estimated CL is somewhat smaller than those reported in other pediatric PK studies. Although our CL estimates cannot be directly compared with other studies which used different 
medRxiv preprint doi: https://doi.org/10.1101/2021.05.03.21256553; this version posted May 6, 2021. The copyright holder for this preprint (which was not certified by peer review) is the author/funder, who has granted medRxiv a license to display the preprint in perpetuity.

All rights reserved. No reuse allowed without permission.

covariate models, in terms of a standard weight of $70 \mathrm{~kg}$ in an allometric scaling model ignoring other covariates, Zuppa et al. ${ }^{9}$ found a post-cardiac bypass CL of $37.3 \mathrm{~L} / \mathrm{hr}$ for neonates and infants age $0-6$ months and $\mathrm{Su}$ et al. ${ }^{15}$ estimated $\mathrm{CL}$ as $39.4 \mathrm{~L} / \mathrm{hr}$ for children age $1-24$ months after open heart surgery. The different results could be related to differences in several factors between studies including study design and study population. For example, our study used sparse and opportunistic sampling and included more heterogenous population while the other two studies used densely measured drug levels and were performed in a well-controlled clinical setting with much younger and more homogeneous population.

In our model, we were also able to detect a statistically significant effect of $U G T 2 B 10$ on CL. Because weight is the most important factor in determining CL for a pediatric population, we can explain the genotype effect in terms of the weight reduction needed to achieve an equivalent decrease in CL among subjects with no variants. Specifically, having any UGT2B10 variant reduces CL by the same amount as a weight decrease of about $20 \%$ [exp(-0.15/0.75)=0.8] for a subject without variants. A detailed calculation is provided in Supplemental Material. This effect can also be interpreted visually; in Figure 2B, a vertical shift from the solid 'no variants' line to the dashed 'any variants' line is equivalent - in terms of predicted CL - to moving along the 'no variants' line to a $20 \%$ lower weight. As an example, a 12-month-old subject with weight $10 \mathrm{~kg}$ and $U G T 2 B 10$ variants has the same CL as a 12 -month-old subject with weight $8 \mathrm{~kg}$ and no variants.

These results imply that subjects with any $U G T 2 B 10$ variant require a smaller dose than those without variants to achieve similar concentration. Simulating a fixed weight basis dosing scheme for a 12-hour infusion, this translates to a dexmedetomidine infusion rate of $5.6 \mathrm{mcg} / \mathrm{hr}$ versus $6.0 \mathrm{mcg} / \mathrm{hr}$ for a 12 -month-old, $10 \mathrm{~kg}$ subject with and without variants, respectively as illustrated in Figure 4A. The same per $\mathrm{kg}$ dosing rates $-0.56 \mathrm{mcg} / \mathrm{kg} / \mathrm{hr}$ versus $0.6 \mathrm{mcg} / \mathrm{kg} / \mathrm{hr}-$ 
medRxiv preprint doi: https://doi.org/10.1101/2021.05.03.21256553; this version posted May 6, 2021. The copyright holder for this preprint (which was not certified by peer review) is the author/funder, who has granted medRxiv a license to display the preprint in perpetuity.

All rights reserved. No reuse allowed without permission.

for 120-month-old, $50 \mathrm{~kg}$ subjects with and without variants is presented in Figure 4B. For these older, heavier subjects overall concentrations are higher, but the PK profile between those with and without variants is similar. Note that the reduction in dose for those with variants is not the same as the $20 \%$ reduction in CL because, in our model, the UGT2B10 genotype does not impact the other PK parameters in the structural model.

Using population PK models derived from EHR data and remnant samples offers the possibility of more accurate prediction of individual dosing requirements in a real-life setting, especially in populations where large, intensive-sampling PK clinical trials are difficult to perform due to ethical or logistical considerations. The results from such model-informed precision dosing could also be integrated back into EHR-embedded decision support tools; the development and implementation of several of these tools has been recently described by Mizuno et al. ${ }^{35}$ and Vinks et al. ${ }^{36}$

There are several limitations related to the use of EHR and remnant samples for our study. Although our data were generated using as a standardized system to construct the PK data, ${ }^{25}$ there may be some data errors due to inherent limitations of EHR data, which is not primarily collected for research use. Also, the specimens are very sparse for some subjects and their collection is not timed to facilitate optimal PK estimation.

Despite these limitations, our study provides further evidence for the feasibility of using EHR data and remnant samples for population PK analysis. Our study findings such as weight effects on CL could be helpful to develop a model-based dosing that could be superior to the current fixed-weight dosing scheme. However, this should be tested in a future study for its clinical utility in the pediatric population. Because dexmedetomidine is used to achieve specific sedation goals, it would also be of interest to incorporate the current study results into a joint 
medRxiv preprint doi: https://doi.org/10.1101/2021.05.03.21256553; this version posted May 6, 2021. The copyright holder for this preprint (which was not certified by peer review) is the author/funder, who has granted medRxiv a license to display the preprint in perpetuity.

All rights reserved. No reuse allowed without permission.

pharmacokinetic-pharmacodynamic model using sedation outcomes also derived from the EHR.

These models are an important step toward the ultimate goal of precision dosing. 
medRxiv preprint doi: https://doi.org/10.1101/2021.05.03.21256553; this version posted May 6, 2021. The copyright holder for this preprint (which was not certified by peer review) is the author/funder, who has granted medRxiv a license to display the preprint in perpetuity.

All rights reserved. No reuse allowed without permission.

\section{Acknowledgements}

The authors thank the Vanderbilt Clinical Laboratory staff for their assistance in obtaining the remnant samples for this research, and the patients and families who participated in this study

\section{Conflict of Interest / Disclosure}

None

\section{Funding}

LC and NTJ are supported by NIH/NIGMS (R01-GM124109). This work was supported in part by NIH/NIGMS (MS), NICHD R01HD084461 and NIH National Center for Advancing Translational Sciences UL1 TR000445 (Vanderbilt CTSA).

\section{Author Contributions}

All authors participated in critical review and revision of the final manuscript and approved the final manuscript draft.

NTJ: Analyzed Data, Performed Research, and Wrote Manuscript.

CB: Performed Research.

SLV: Performed Research, and Wrote Manuscript.

PK: Designed Research, and Wrote Manuscript.

LC: Designed Research, Analyzed Data, Performed Research, and Wrote Manuscript. 
medRxiv preprint doi: https://doi.org/10.1101/2021.05.03.21256553; this version posted May 6, 2021. The copyright holder for this preprint (which was not certified by peer review) is the author/funder, who has granted medRxiv a license to display the preprint in perpetuity.

\section{References}

1. Plambech, M. Z. \& Afshari, A. Dexmedetomidine in the pediatric population: a review. MINERVA Anestesiol. 81, 13 (2015).

2. Weerink, M. A. S. et al. Clinical Pharmacokinetics and Pharmacodynamics of Dexmedetomidine. Clin. Pharmacokinet. 56, 893-913 (2017).

3. Schwartz, L. I. et al. The Perioperative Use of Dexmedetomidine in Pediatric Patients with Congenital Heart Disease: An Analysis from the Congenital Cardiac Anesthesia SocietySociety of Thoracic Surgeons Congenital Heart Disease Database. Anesth. Analg. 123, 715721 (2016).

4. Shuplock, J. M. et al. Association between perioperative dexmedetomidine and arrhythmias after surgery for congenital heart disease. Circ. Arrhythm. Electrophysiol. 8, 643-650 (2015).

5. Takeuchi, M. et al. Age-Specific Dose Regimens of Dexmedetomidine for Pediatric Patients in Intensive Care Following Elective Surgery: A Phase 3, Multicenter, Open-Label Clinical Trial in Japan. Pediatr. Crit. Care Med. Publish Ahead of Print, (2021).

6. Morse, J. D., Cortinez, L. I. \& Anderson, B. J. A Universal Pharmacokinetic Model for Dexmedetomidine in Children and Adults. J. Clin. Med. 9, 3480 (2020).

7. Damian, M. A. et al. Pharmacokinetics of Dexmedetomidine in Infants and Children After Orthotopic Liver Transplantation: Anesth. Analg. 130, 209-216 (2020).

8. Ber, J. et al. Population Pharmacokinetic Model of Dexmedetomidine in a Heterogeneous Group of Patients. J. Clin. Pharmacol. 60, 1461-1473 (2020).

9. Zuppa, A. F. et al. Results of a phase 1 multicentre investigation of dexmedetomidine bolus and infusion in corrective infant cardiac surgery. Br. J. Anaesth. 123, 839-852 (2019). 
medRxiv preprint doi: https://doi.org/10.1101/2021.05.03.21256553; this version posted May 6, 2021. The copyright holder for this preprint (which was not certified by peer review) is the author/funder, who has granted medRxiv a license to display the preprint in perpetuity. All rights reserved. No reuse allowed without permission.

10. Zimmerman, K. O. et al. Dexmedetomidine Pharmacokinetics and a New Dosing Paradigm in Infants Supported With Cardiopulmonary Bypass: Anesth. Analg. 129, 15191528 (2019).

11. Song, I.-K. et al. A Population Pharmacokinetic Model of Intravenous Dexmedetomidine for Mechanically Ventilated Children after Neurosurgery. J. Clin. Med. 8, 1563 (2019).

12. Pérez-Guillé, M.-G. et al. Population Pharmacokinetics and Pharmacodynamics of Dexmedetomidine in Children Undergoing Ambulatory Surgery: Anesth. Analg. 127, 716-723 (2018).

13. Smuszkiewicz, P. et al. Pharmacokinetics of dexmedetomidine during analgosedation in ICU patients. J. Pharmacokinet. Pharmacodyn. 45, 277-284 (2018).

14. Greenberg, R. G. et al. Population Pharmacokinetics of Dexmedetomidine in Infants: Journal of Clinical Pharmacology. J. Clin. Pharmacol. 57, 1174-1182 (2017).

15. Su, F. et al. Dexmedetomidine Pharmacology in Neonates and Infants After Open Heart Surgery: Anesth. Analg. 122, 1556-1566 (2016).

16. Wiczling, P. et al. The pharmacokinetics of dexmedetomidine during long-term infusion in critically ill pediatric patients. A Bayesian approach with informative priors. $J$.

Pharmacokinet. Pharmacodyn. 43, 315-324 (2016).

17. Potts, A. L. et al. Dexmedetomidine pharmacokinetics in pediatric intensive care - a pooled analysis. Pediatr. Anesth. 19, 1119-1129 (2009).

18. DEXMEDETOMIDINE HCL injection [package insert]. (Hikma Pharmaceuticals USA Inc., Berkeley Heights, NJ, 2020).at <https://dailymed.nlm.nih.gov/dailymed/drugInfo.cfm?setid=de6f01a2-9f2d-4c68-9c0206643704acb1>

19. Kohli, U. et al. CYP2A6 genetic variation and dexmedetomidine disposition. Eur. J. Clin. Pharmacol. 68, 937-942 (2012). 
medRxiv preprint doi: https://doi.org/10.1101/2021.05.03.21256553; this version posted May 6, 2021. The copyright holder for this preprint (which was not certified by peer review) is the author/funder, who has granted medRxiv a license to display the preprint in perpetuity. All rights reserved. No reuse allowed without permission.

20. Rolle, A. et al. Dexmedetomidine metabolic clearance is not affected by fat mass in obese patients. Br. J. Anaesth. 120,969-977 (2018).

21. El-Boraie, A. et al. Evaluation of a weighted genetic risk score for the prediction of biomarkers of CYP2A6 activity. Addict. Biol. 25, e12741 (2020).

22. Van Driest, S. L. et al. Pragmatic pharmacology: population pharmacokinetic analysis of fentanyl using remnant samples from children after cardiac surgery. Br. J. Clin. Pharmacol. 81, 1165-1174 (2016).

23. Hagos, F. T. et al. Factors Contributing to Fentanyl Pharmacokinetic Variability Among Diagnostically Diverse Critically Ill Children. Clin. Pharmacokinet. 58, 1567-1576 (2019).

24. Van Driest, S. L. \& Choi, L. Real-World Data for Pediatric Pharmacometrics: Can We Upcycle Clinical Data for Research Use? Clin. Pharmacol. Ther. 106, 84-86 (2019).

25. Choi, L. et al. Development of a System for Postmarketing Population Pharmacokinetic and Pharmacodynamic Studies Using Real-World Data From Electronic Health Records. Clin. Pharmacol. Ther. 107, 934-943 (2020).

26. EHR: Electronic Health Record (EHR) Data Processing and Analysis Tool. (2020).

27. Harris, P. A. et al. Research electronic data capture (REDCap) - A metadata-driven methodology and workflow process for providing translational research informatics support. J. Biomed. Inform. 42, 377-381 (2009).

28. R Core Team R: A Language and Environment for Statistical Computing. (R Foundation for Statistical Computing, Vienna, Austria, 2020).at <https://www.R-project.org/>

29. Monolix. (Lixoft SAS, Antony, France, 2020). at <https://monolix.lixoft.com/>

30. Ahn, J. E., Karlsson, M. O., Dunne, A. \& Ludden, T. M. Likelihood based approaches to handling data below the quantification limit using NONMEM VI. $J$ Pharmacokinet Pharmacodyn 21 (2008). 
medRxiv preprint doi: https://doi.org/10.1101/2021.05.03.21256553; this version posted May 6, 2021. The copyright holder for this preprint

(which was not certified by peer review) is the author/funder, who has granted medRxiv a license to display the preprint in perpetuity.

All rights reserved. No reuse allowed without permission.

31. Jacobs, M. L. et al. An empirically based tool for analyzing morbidity associated with operations for congenital heart disease. J. Thorac. Cardiovasc. Surg. 145, 1046-1057.e1 (2013).

32. Badée, J. et al. Characterization of the Ontogeny of Hepatic UDP-

Glucuronosyltransferase Enzymes Based on Glucuronidation Activity Measured in Human

Liver Microsomes. J. Clin. Pharmacol. 59, S42-S55 (2019).

33. Sukarnjanaset, W., Wattanavijitkul, T. \& Jarurattanasirikul, S. Evaluation of FOCEI and SAEM Estimation Methods in Population Pharmacokinetic Analysis Using NONMEM® Across Rich, Medium, and Sparse Sampling Data. Eur. J. Drug Metab. Pharmacokinet. 43, 729-736 (2018).

34. Baron, K. T. mrgsolve: Simulate from ODE-Based Models. (2020).at <https://CRAN.Rproject.org/package $=$ mrgsolve $>$

35. Mizuno, T., Dong, M., Taylor, Z. L., Ramsey, L. B. \& Vinks, A. A. Clinical implementation of pharmacogenetics and model-informed precision dosing to improve patient care. Br. J. Clin. Pharmacol. n/a,

36. Vinks, A. A. et al. Electronic Health Record-Embedded Decision Support Platform for Morphine Precision Dosing in Neonates. Clin. Pharmacol. Ther. 107, 186-194 (2020). 
medRxiv preprint doi: https://doi.org/10.1101/2021.05.03.21256553; this version posted May 6, 2021. The copyright holder for this preprint (which was not certified by peer review) is the author/funder, who has granted medRxiv a license to display the preprint in perpetuity. All rights reserved. No reuse allowed without permission.

Table 1. Study Cohort

Summary of demographic, genotype, clinical, dosing, and specimen sampling characteristics

\begin{tabular}{|c|c|}
\hline & Entire cohort \\
\hline $\mathrm{n}$ & 354 \\
\hline Age (months)* & $15.7(5.3-61.8)$ \\
\hline Median weight $(\mathrm{kg})^{*}$ & $9.41(6.0-18.2)$ \\
\hline Male sex $\dagger$ & $183(52 \%)$ \\
\hline \multicolumn{2}{|l|}{ Race $\dagger$} \\
\hline White & $293(83 \%)$ \\
\hline Black & $40(11 \%)$ \\
\hline American Indian or Alaska Native & $2(1 \%)$ \\
\hline Asian & $6(2 \%)$ \\
\hline Other & $5(1 \%)$ \\
\hline Unknown & $8(2 \%)$ \\
\hline Median serum creatinine $(\mathrm{mg} / \mathrm{dl})^{*}$ & $0.49(0.44-0.56)$ \\
\hline \multicolumn{2}{|l|}{ STAT score $\dagger$} \\
\hline 1 & $154(44 \%)$ \\
\hline 2 & $108(31 \%)$ \\
\hline 3 & $41(12 \%)$ \\
\hline 4 & $46(13 \%)$ \\
\hline 5 & $5(1 \%)$ \\
\hline \multicolumn{2}{|l|}{ UGT1A4 variants† } \\
\hline 0 & $262(74 \%)$ \\
\hline 1 & $87(25 \%)$ \\
\hline 2 & $5(1 \%)$ \\
\hline \multicolumn{2}{|l|}{$U G T 2 B 10$ variants $\dagger$} \\
\hline 0 & $186(53 \%)$ \\
\hline 1 & $117(33 \%)$ \\
\hline 2 or 3 & $51(14 \%)$ \\
\hline$C Y P 2 A 6$ score $* \neq$ & $2.04(2.00-2.21)$ \\
\hline Cardiac bypass time $(\min )^{*}$ & $100(71-144)$ \\
\hline Length of ICU hospitalization (days)* & $4(2-6)$ \\
\hline Total dosing events & 2386 \\
\hline Dosing events per subject* & $5(3-8)$ \\
\hline Total sampled specimens & 1400 \\
\hline Specimens below lower limit of quantification & 120 \\
\hline Sampled specimens per subject* & $3(2-5)$ \\
\hline
\end{tabular}

* Median (interquartile range); $\uparrow$ Number (\%); + Among $n=350$ subjects with available score 
Table 2. Estimates of Parameters for Population Pharmacokinetic Models

(A) Estimates from base model and covariate models without genetic covariates. Weight is modeled with fixed allometric scaling parameters.

\begin{tabular}{|c|c|c|c|c|c|}
\hline \multicolumn{2}{|c|}{ Base Model } & \multicolumn{2}{|c|}{ Weight Only Model } & \multicolumn{2}{|c|}{ Weight and Age model } \\
\hline $\begin{array}{c}\text { Parameters } \\
(\mathrm{Obj}=-1517.34)\end{array}$ & $\begin{array}{c}\text { Estimates (SE) } \\
{[95 \% \mathrm{CI}] \dagger}\end{array}$ & $\begin{array}{c}\text { Parameters } \\
(\mathrm{Obj}=-1923.32)\end{array}$ & $\begin{array}{c}\text { Estimates (SE) } \\
{[95 \% \mathrm{CI}]}\end{array}$ & $\begin{array}{c}\text { Parameters } \\
(\mathrm{Obj}=-1932.37)\end{array}$ & $\begin{array}{c}\text { Estimates (SE) } \\
{[95 \% \mathrm{CI}]}\end{array}$ \\
\hline $\mathrm{CL}$ & & $\mathrm{CL}=\theta_{1}(\mathrm{WT} / 70)^{0.75}$ & & $\mathrm{CL}=\theta_{1}(\mathrm{WT} / 70)^{0.75} \exp \left(\theta_{5} \mathrm{AGE}\right)$ & \\
\hline & $\begin{array}{l}6.27(0.52) \\
{[5.33,7.37]}\end{array}$ & $\theta_{1}$ & $\begin{array}{l}22.3(1.85) \\
{[19.0,26.2]}\end{array}$ & $\theta_{1}$ & $\begin{array}{c}19.4(1.67) \\
{[16.4,22.9]}\end{array}$ \\
\hline & & & & $\theta_{5}$ & $\begin{array}{c}0.00126(0.00061) \\
{[6.47 \mathrm{e}-05,0.00246]}\end{array}$ \\
\hline $\mathrm{V}_{1}$ & & $\mathrm{~V}_{1}=\theta_{2}(\mathrm{WT} / 70)$ & & $\mathrm{V}_{1}=\theta_{2}(\mathrm{WT} / 70)$ & \\
\hline & $\begin{array}{c}19.5(1.37) \\
{[17.0,22.4]}\end{array}$ & $\theta_{2}$ & $\begin{array}{l}123(11.5) \\
{[102,148]}\end{array}$ & $\theta_{2}$ & $\begin{array}{c}144(12) \\
{[122,169]}\end{array}$ \\
\hline Q & & $\mathrm{Q}=\theta_{3}(\mathrm{WT} / 70)^{0.75}$ & & $\mathrm{Q}=\theta_{3}(\mathrm{WT} / 70)^{0.75}$ & \\
\hline & $\begin{array}{c}5.26(0.442) \\
{[4.47,6.2]}\end{array}$ & $\theta_{3}$ & $\begin{array}{l}26.6(2.23) \\
{[22.6,31.3]}\end{array}$ & $\theta_{3}$ & $\begin{array}{c}28.8(2.03) \\
{[25.1,33]}\end{array}$ \\
\hline $\mathrm{V}_{2}$ & & $\mathrm{~V}_{2}=\theta_{4}(\mathrm{WT} / 70)$ & & $\mathrm{V}_{2}=\theta_{4}(\mathrm{WT} / 70)$ & \\
\hline & $\begin{array}{c}763(126) \\
{[555,1050]}\end{array}$ & $\theta_{4}$ & $\begin{array}{c}6670(1500) \\
{[4360,10200]}\end{array}$ & $\theta_{4}$ & $\begin{array}{c}10200(1780) \\
{[7280,14200]}\end{array}$ \\
\hline$\omega_{\mathrm{CL}}(\% \mathrm{CV})$ & $201(12)[178,226]$ & $\omega_{\mathrm{CL}}(\% \mathrm{CV})$ & $123(13)[100,150]$ & $\omega_{\mathrm{CL}}(\% \mathrm{CV})$ & $126(12)[105,151]$ \\
\hline$\omega_{\mathrm{V} 1}(\% \mathrm{CV})$ & $161(9)[145,179]$ & $\omega_{\mathrm{V} 1}(\% \mathrm{CV})$ & $168(22)[130,217]$ & $\omega_{\mathrm{V} 1}(\% \mathrm{CV})$ & $147(16)[119,182]$ \\
\hline$\omega_{\mathrm{Q}}(\% \mathrm{CV})$ & $146(8)[132,162]$ & $\omega_{\mathrm{Q}}(\% \mathrm{CV})$ & $91(11)[71,115]$ & $\omega_{\mathrm{Q}}(\% \mathrm{CV})$ & $81(9)[65,99]$ \\
\hline$\omega_{\mathrm{V} 2}(\% \mathrm{CV})$ & $672(81)[534,855]$ & $\omega_{\mathrm{V} 2}(\% \mathrm{CV})$ & $857(256)[494,1595]$ & $\omega_{\mathrm{V} 2}(\% \mathrm{CV})$ & $720(192)[439,1251]$ \\
\hline$\sigma_{\text {add }}(\mathrm{ng} / \mathrm{mL})$ & $\begin{array}{c}2.22 \mathrm{e}-16(5.65 \mathrm{e}-13)[0 \\
1.11 \mathrm{e}-12]\end{array}$ & $\sigma_{\text {add }}(\mathrm{ng} / \mathrm{mL})$ & $\begin{array}{c}1.9 \mathrm{e}-08(3.73 \mathrm{e}-07) \\
{[0,7.51 \mathrm{e}-07]}\end{array}$ & $\sigma_{\text {add }}(\mathrm{ng} / \mathrm{mL})$ & $\begin{array}{c}3.14 \mathrm{e}-10(8.86 \mathrm{e}-09) \\
{[0,1.77 \mathrm{e}-08]}\end{array}$ \\
\hline$\sigma_{\text {prop }}(\mathrm{ng} / \mathrm{mL})$ & $\begin{array}{c}0.475(0.0117)[0.452 \\
0.498]\end{array}$ & $\sigma_{\text {prop }}(\mathrm{ng} / \mathrm{mL})$ & $\begin{array}{l}0.475(0.0133) \\
{[0.449,0.501]}\end{array}$ & $\sigma_{\text {prop }}(\mathrm{ng} / \mathrm{mL})$ & $\begin{array}{l}0.478(0.0132) \\
{[0.452,0.504]}\end{array}$ \\
\hline
\end{tabular}


(B) Estimates from final gene models for UGT1A4 or UGT2B10 with weight and age.

\begin{tabular}{|c|c|c|c|}
\hline \multicolumn{2}{|l|}{ UGT1A4 Gene Model } & \multicolumn{2}{|l|}{ UGT2B10 Gene Model } \\
\hline $\begin{array}{c}\text { Parameters } \\
(\mathrm{Obj}=-1936.425)\end{array}$ & $\begin{array}{l}\text { Estimates (SE) } \\
{[95 \% \mathrm{CI}]}\end{array}$ & $\begin{array}{c}\text { Parameters } \\
(\mathrm{Obj}=-1935.175)\end{array}$ & $\begin{array}{l}\text { Estimates (SE) } \\
{[95 \% \mathrm{CI}]}\end{array}$ \\
\hline $\mathrm{CL}=\theta_{1}(\mathrm{WT} / 70)^{0.75} \exp \left(\theta_{5} \mathrm{AGE}+\theta_{6} \mathrm{I}[\mathrm{UGT} 1 \mathrm{~A} 4>0]\right)$ & & $\mathrm{CL}=\theta_{1}(\mathrm{WT} / 70)^{0.75} \exp \left(\theta_{5} \mathrm{AGE}+\theta_{6} \mathrm{I}[\mathrm{UGT} 2 \mathrm{~B} 10>0]\right)$ & \\
\hline$\theta_{1}$ & $19.4(1.92)[16.0,23.6]$ & $\theta_{1}$ & $22.3(2.3)[18.3,27.3]$ \\
\hline$\theta_{5}$ & $\begin{array}{c}0.00175(0.000562) \\
{[0.000651,0.00285]}\end{array}$ & $\theta_{5}$ & $\begin{array}{l}0.00185(0.000409) \\
{[0.00105,0.00265]}\end{array}$ \\
\hline$\theta_{6}$ & $\begin{array}{c}-0.0765(0.0938) \\
{[-0.26,0.107]}\end{array}$ & $\theta_{6}$ & $\begin{array}{c}-0.151(0.062) \\
{[-0.272,-0.0295]}\end{array}$ \\
\hline $\mathrm{V}_{1}=\theta_{2}(\mathrm{WT} / 70)$ & & $\mathrm{V}_{1}=\theta_{2}(\mathrm{WT} / 70)$ & \\
\hline$\theta_{2}$ & $135(12.6)[112,161]$ & $\theta_{2}$ & $133(11.4)[112,157]$ \\
\hline $\mathrm{Q}=\theta_{3}(\mathrm{WT} / 70)^{0.75}$ & & $\mathrm{Q}=\theta_{3}(\mathrm{WT} / 70)^{0.75}$ & \\
\hline$\theta_{3}$ & $28.1(2.18)[24.1,32.7]$ & $\theta_{3}$ & $24.1(2.68)[19.4,29.9]$ \\
\hline $\mathrm{V}_{2}=\theta_{4}(\mathrm{WT} / 70)$ & & $\mathrm{V}_{2}=\theta_{4}(\mathrm{WT} / 70)$ & \\
\hline$\theta_{4}$ & $9400(1850)[6460,13700]$ & $\theta_{4}$ & $5230(1270)[3310,8260]$ \\
\hline$\omega_{\mathrm{CL}}(\% \mathrm{CV})$ & $121(13)[98,149]$ & $\omega_{\mathrm{CL}}(\% \mathrm{CV})$ & $124(13)[100,153]$ \\
\hline$\omega_{\mathrm{V} 1}(\% \mathrm{CV})$ & $161(21)[125,209]$ & $\omega_{\mathrm{V} 1}(\% \mathrm{CV})$ & $149(14)[124,180]$ \\
\hline$\omega_{\mathrm{Q}}(\% \mathrm{CV})$ & $87(10)[69,108]$ & $\omega_{\mathrm{Q}}(\% \mathrm{CV})$ & $110(17)[81,148]$ \\
\hline$\omega_{\mathrm{V} 2}(\% \mathrm{CV})$ & $867(238)[520,1531]$ & $\omega_{\mathrm{V} 2}(\% \mathrm{CV})$ & $861(304)[451,1808]$ \\
\hline$\sigma_{\text {add }}(\mathrm{ng} / \mathrm{mL})$ & $\begin{array}{c}1.8 \mathrm{e}-07(4.12 \mathrm{e}-06) \\
{[0,8.25 \mathrm{e}-06]}\end{array}$ & $\sigma_{\text {add }}(\mathrm{ng} / \mathrm{mL})$ & $\begin{array}{c}1.46 \mathrm{e}-08(2.64 \mathrm{e}-07) \\
{[0,5.32 \mathrm{e}-07]}\end{array}$ \\
\hline$\sigma_{\text {prop }}(\mathrm{ng} / \mathrm{mL})$ & $\begin{array}{c}0.476(0.0135) \\
{[0.45,0.503]}\end{array}$ & $\sigma_{\text {prop }}(\mathrm{ng} / \mathrm{mL})$ & $\begin{array}{l}0.479(0.0138) \\
{[0.452,0.506]}\end{array}$ \\
\hline
\end{tabular}

Abbreviations: $\uparrow 95 \%$ Asymptotic confidence intervals (CIs); SE, standard error; Obj, objective function value; CL, total clearance (L/hr); Q, intercompartmental clearance $(\mathrm{L} / \mathrm{hr}) ; \mathrm{V}_{1}$, volume of distribution for the central compartment $(\mathrm{L}) ; \mathrm{V}_{2}$, volume of distribution for the peripheral compartment (L); CV, coefficient of variation; WT, body weight in kg; AGE, age in months; $\omega_{\mathrm{CL}}, \omega_{\mathrm{V} 1}, \omega_{\mathrm{Q}}, \omega_{\mathrm{V} 2}$, the standard deviation for $\eta_{\mathrm{i}}{ }^{\mathrm{CL}}$ $, \eta_{\mathrm{i}} \mathrm{V}_{1}, \eta_{\mathrm{i}}^{\mathrm{Q}}$, and $\eta_{\mathrm{i}} \mathrm{V}_{2}$, respectively; For the standard deviation of random effects, $\omega$, coefficient of variation was calculated as $\mathrm{CV} \%=$ $100 \times \sqrt{\left(\exp \left(\omega^{2}\right)-1\right)} ; \sigma_{\text {prop }}$ and $\sigma_{\text {add }}$ are the proportional and additive terms, respectively, in the residual error model 
medRxiv preprint doi: https://doi.org/10.1101/2021.05.03.21256553; this version posted May 6, 2021. The copyright holder for this preprint (which was not certified by peer review) is the author/funder, who has granted medRxiv a license to display the preprint in perpetuity. All rights reserved. No reuse allowed without permission.

\section{Figure 1: Population PK model diagnostic plots for UGT2B10 model.}

(A) Observed dexmedetomidine concentrations vs. population (left) and individual (right) predicted concentrations
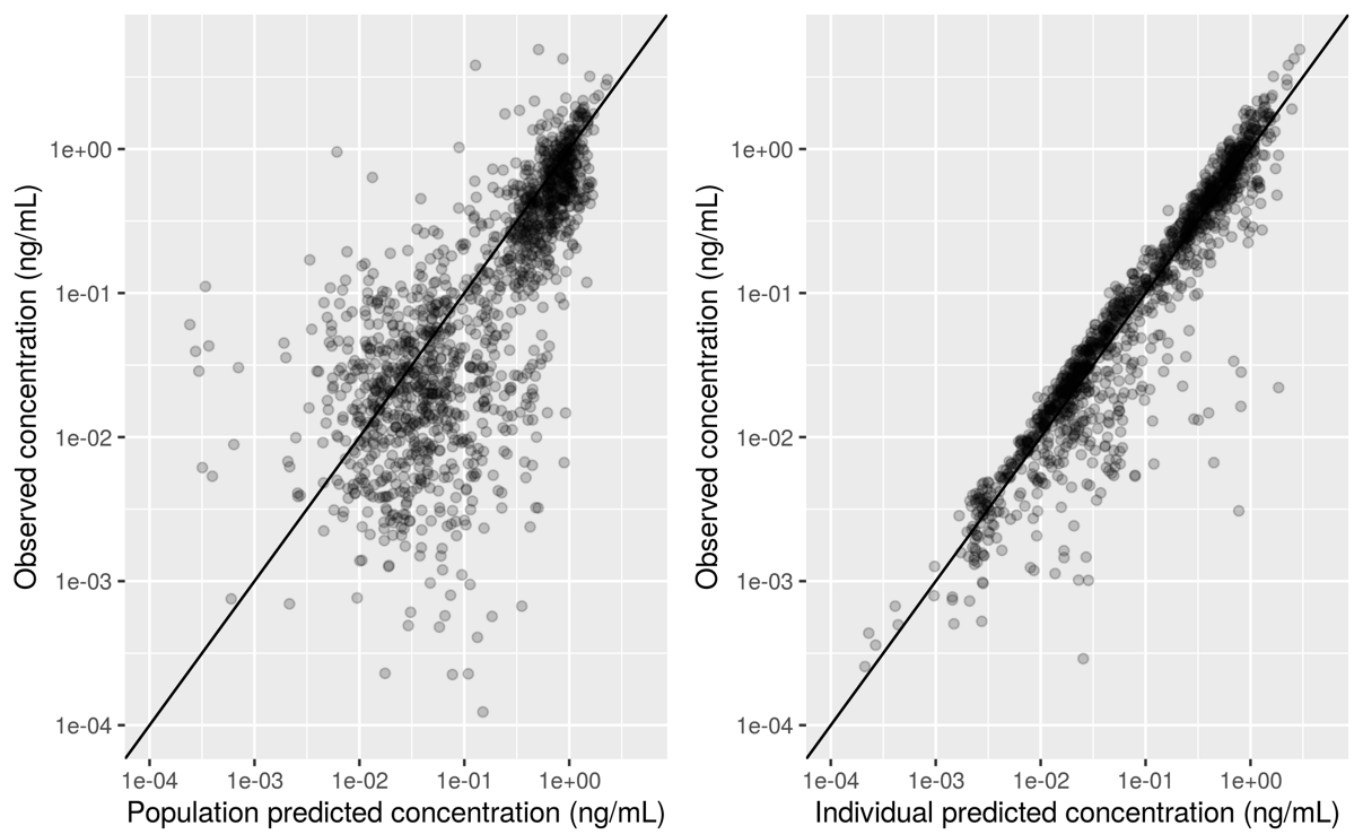

(B) Individual weighted residuals vs. predicted concentrations (left) and time (right)
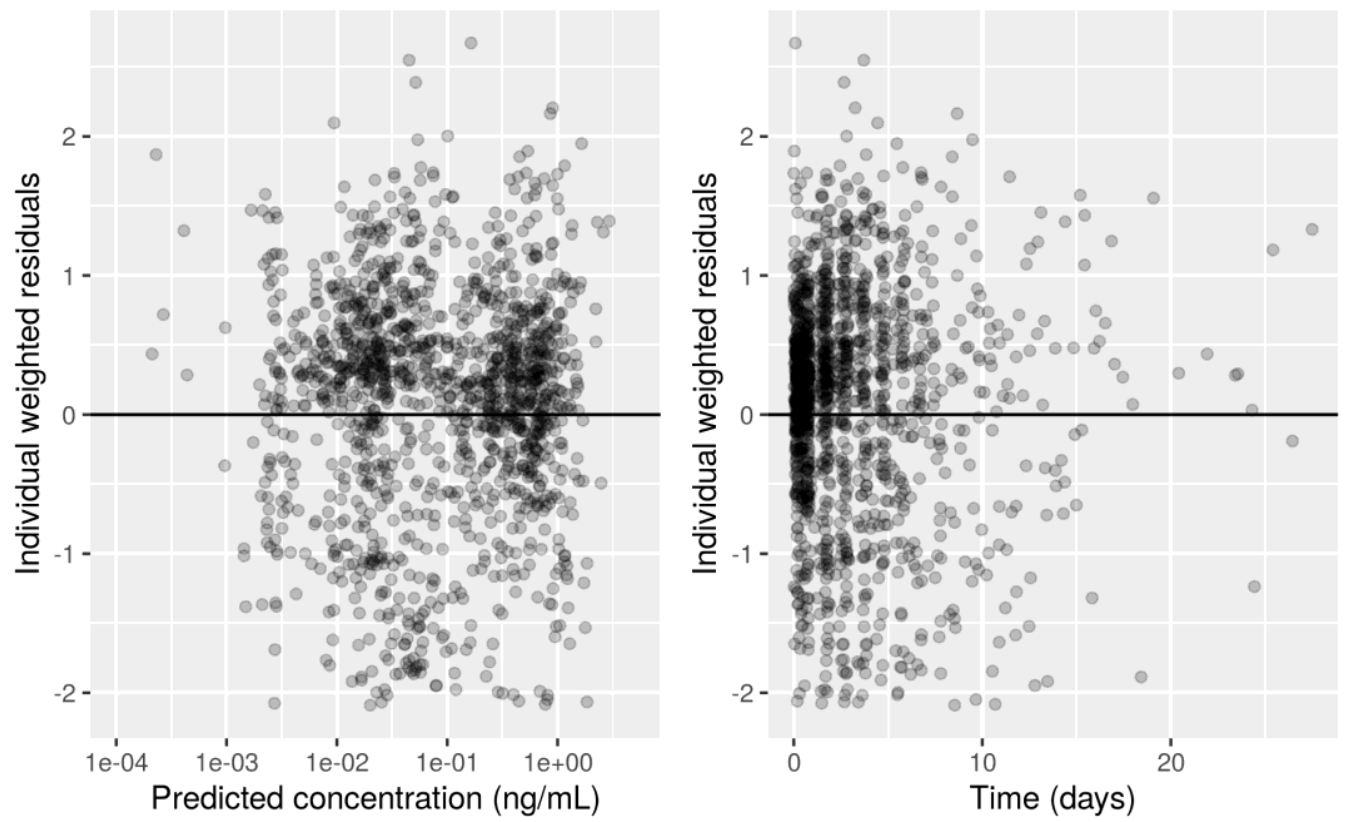
medRxiv preprint doi: https://doi.org/10.1101/2021.05.03.21256553; this version posted May 6, 2021. The copyright holder for this preprint (which was not certified by peer review) is the author/funder, who has granted medRxiv a license to display the preprint in perpetuity.

All rights reserved. No reuse allowed without permission.

(C) Visual predictive check, where $10^{\text {th }}, 50^{\text {th }}$ and $90^{\text {th }}$ percentile of observed values (solid lines)

and theoretical values (dashed lines) along with $90 \%$ prediction interval for theoretical

percentiles (shaded region) are presented.

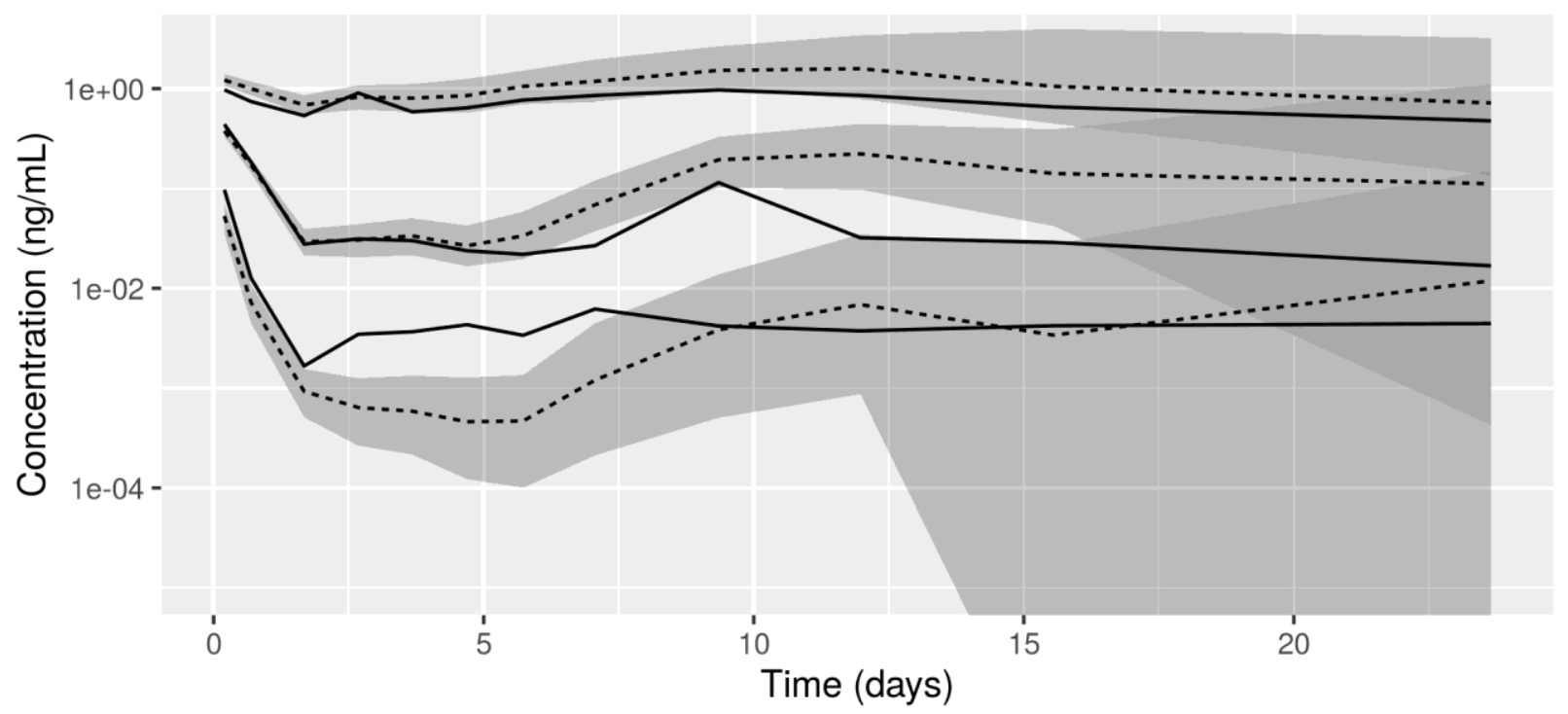

10th, median, 90th percentiles

$90 \%$ prediction interval

empirical

theoretical

-... theoretical 
medRxiv preprint doi: https://doi.org/10.1101/2021.05.03.21256553; this version posted May 6, 2021. The copyright holder for this preprint (which was not certified by peer review) is the author/funder, who has granted medRxiv a license to display the preprint in perpetuity. All rights reserved. No reuse allowed without permission.

Figure 2: Predicted clearance by weight for selected ages. Plausible weight ranges for each age group are: 6 months (5 - $12 \mathrm{~kg}), 12$ months (6 - $13 \mathrm{~kg}), 24$ months ( 8 - $16 \mathrm{~kg}), 48$ months (12 - $22 \mathrm{~kg}), 72$ months (15 - $28 \mathrm{~kg}), 90$ months (18 - $35 \mathrm{~kg}), 120$ months (23 - $50 \mathrm{~kg})$. Overlapping lines between different age categories represent weights that are plausible for multiple ages.

(A) Weight and age model



(B) UGT2B10 gene model

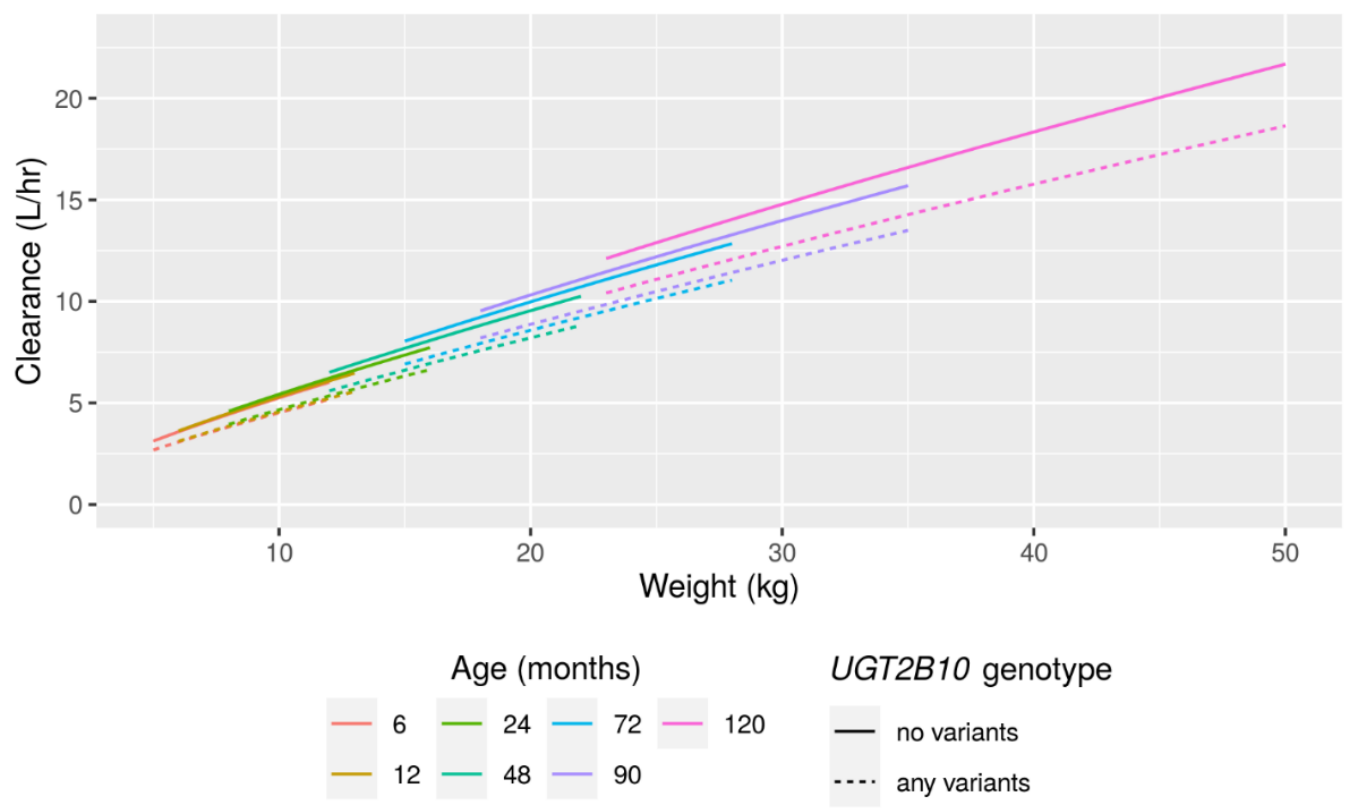


medRxiv preprint doi: https://doi.org/10.1101/2021.05.03.21256553; this version posted May 6, 2021. The copyright holder for this preprint (which was not certified by peer review) is the author/funder, who has granted medRxiv a license to display the preprint in perpetuity.

All rights reserved. No reuse allowed without permission.

Figure 3: Predicted concentration by $U G T 2 B 10$ genotype for combinations of $5^{\text {th }}$, median, and $95^{\text {th }}$ percentile of weight and age and fixed dosing of 0.3 or $0.6 \mathrm{mcg} / \mathrm{kg} / \mathrm{hr}$ for a 12 -hour

infusion. The colored regions with blue (no variants) and orange (any variants) are the 90\%

confidence regions estimated based on 200 simulations. Gray bands represent target

concentration range of 0.4 to $0.8 \mathrm{ng} / \mathrm{mL}$.

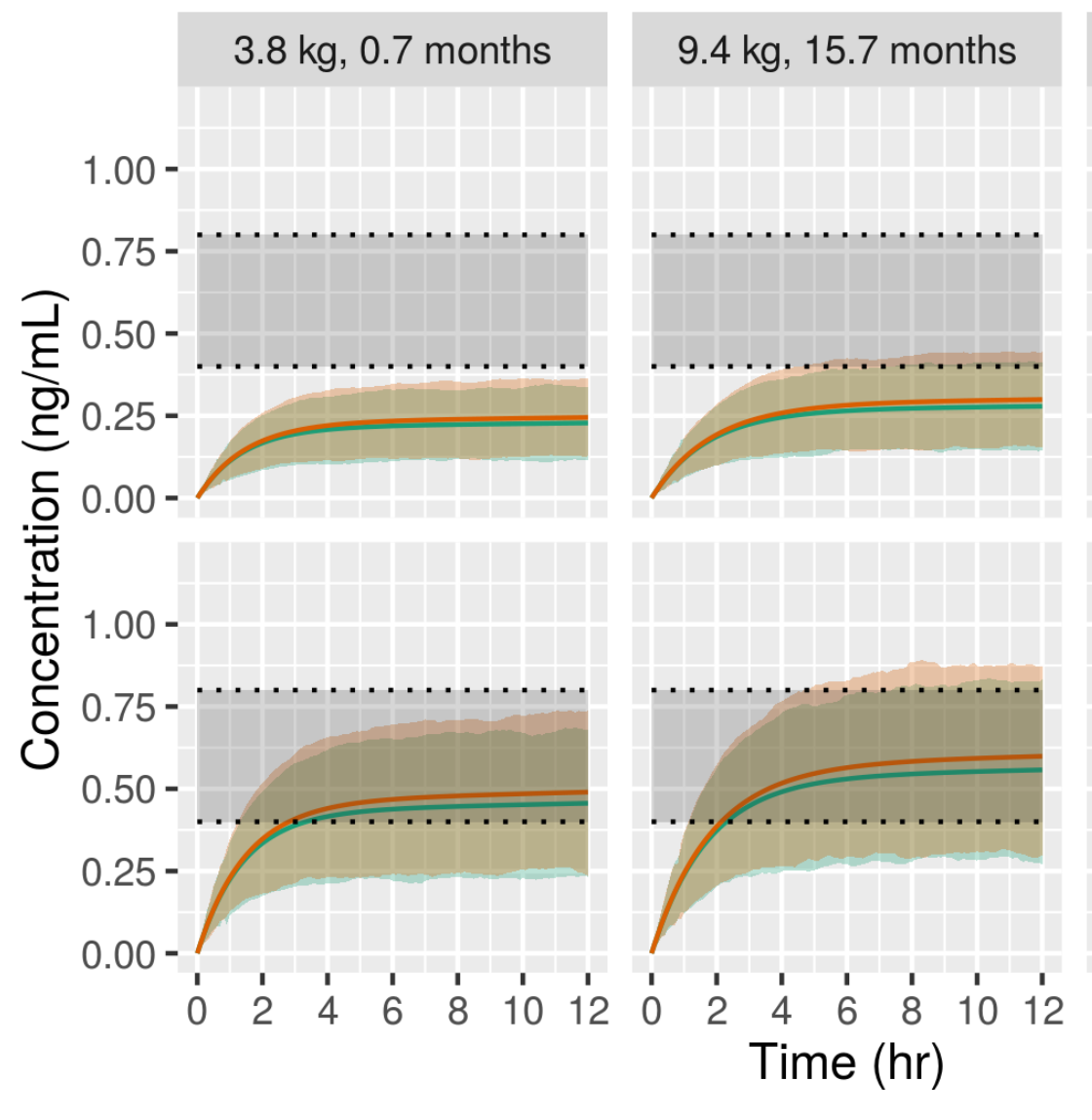

$64.7 \mathrm{~kg}, 203.4$ months




medRxiv preprint doi: https://doi.org/10.1101/2021.05.03.21256553; this version posted May 6, 2021. The copyright holder for this preprint (which was not certified by peer review) is the author/funder, who has granted medRxiv a license to display the preprint in perpetuity.

All rights reserved. No reuse allowed without permission.

Figure 4: Simulated dose needed to achieve similar concentration profiles. A lower dosing rate of $0.56 \mathrm{mcg} / \mathrm{kg} / \mathrm{hr}$ is needed for subjects with $U G T 2 B 10$ variants compared to a dosing rate of $0.6 \mathrm{mcg} / \mathrm{kg} / \mathrm{hr}$ for those without $U G T 2 B 10$ variants. Gray bands represent target concentration range of 0.4 to $0.8 \mathrm{ng} / \mathrm{mL}$.

(A) $10 \mathrm{~kg}$ 12-month child



(B) $50 \mathrm{~kg}$ 120-month child

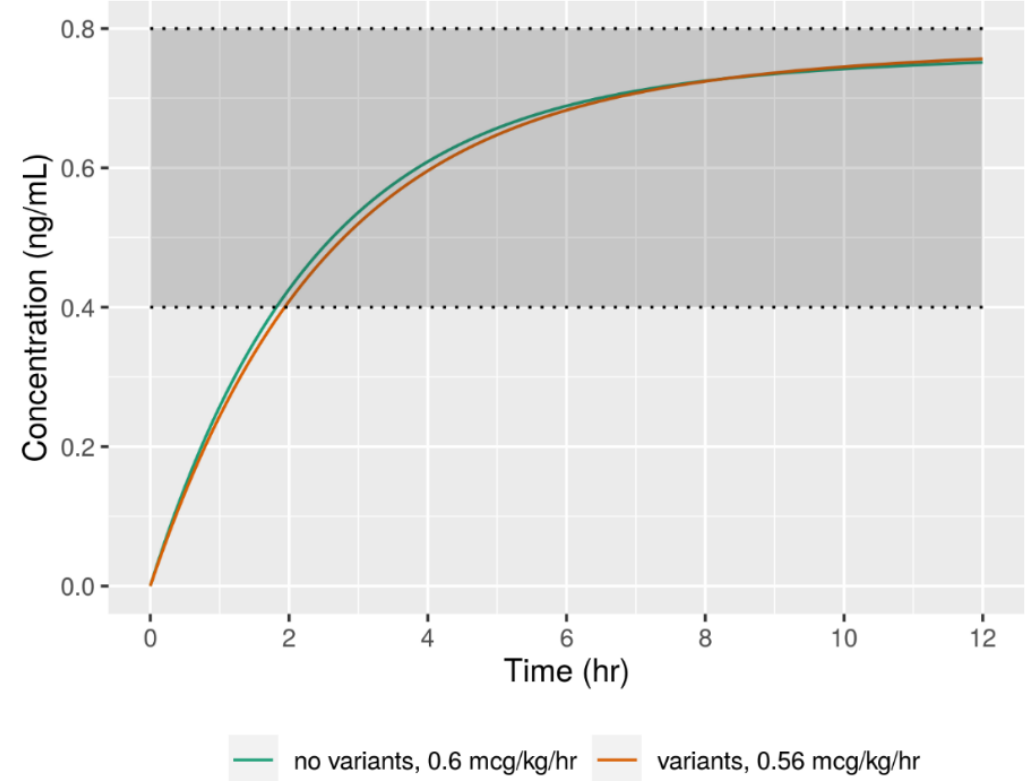

